\title{
Alterations in Red Blood Cell Functionality Induced by an Indole Scaffold Containing a Y-Iminodiketo Moiety: Potential Antiproliferative Conditions
}

\author{
Angela Scala, ${ }^{1}$ Silvana Ficarra, ${ }^{1}$ Annamaria Russo, ${ }^{1}$ Davide Barreca, ${ }^{1}$ Elena Giunta, \\ Antonio Galtieri, ${ }^{1}$ Giovanni Grassi, ${ }^{1}$ and Ester Tellone ${ }^{1}$ \\ ${ }^{1}$ Dipartimento di Scienze Chimiche, Biologiche, Farmaceutiche ed Ambientali, Università di Messina, \\ Viale F. Stagno d'Alcontres 31, 98166 Messina, Italy \\ ${ }^{2}$ Virologia e Microbiologia AOOR Papardo-Piemonte, Viale F. Stagno d'Alcontres, 98166 Messina, Italy \\ Correspondence should be addressed to Giovanni Grassi; ggrassi@unime.it
}

Received 17 February 2016; Revised 6 July 2016; Accepted 11 July 2016

Academic Editor: Svetlana Karakhanova

Copyright (C) 2016 Angela Scala et al. This is an open access article distributed under the Creative Commons Attribution License, which permits unrestricted use, distribution, and reproduction in any medium, provided the original work is properly cited.

\begin{abstract}
We have recently proposed a new erythrocyte-based model of study to predict the antiproliferative effects of selected heterocyclic scaffolds. Starting from the metabolic similarity between erythrocytes and cancer cells, we have demonstrated how the metabolic derangement induced by an indolone-based compound (DPIT) could be related to its antiproliferative effects. In order to prove the validity of our biochemical approach, in the present study the effects on erythrocyte functionality of its chemical precursor (PID), whose synthesis we reported, were investigated. The influence of the tested compound on band 3 protein (B3), oxidative state, ATP efflux, caspase 3, metabolism, intracellular $\mathrm{pH}$, and $\mathrm{Ca}^{2+}$ homeostasis has been evaluated. PID crosses the membrane localizing into the cytosol, increases anion exchange, induces direct caspase activation, shifts the erythrocytes towards an oxidative state, and releases less ATP than in normal conditions. Analysis of phosphatidylserine externalization shows that PID slightly induces apoptosis. Our findings indicate that, due to its unique features, erythrocyte responses to exogenous molecular stimuli can be fruitfully correlated at structurally more complex cells, such as cancer cells. Overall, our work indicates that erythrocyte is a powerful study tool to elucidate the biochemical/biological effects of selected heterocycles opening considerable perspectives in the field of drug discovery.
\end{abstract}

\section{Introduction}

Red blood cells (RBCs) are by far the most abundant cells in the blood and the simplest cells found in mammals. Due to the uniqueness of the direct relationship with each type of cell soma and owing to a metabolism greatly limited compared to other cells, RBC has become an unmatched and efficient model of scientific studies in biochemical and clinical researches $[1,2]$. Its availability, the easy handling and preparation, and its natural "dispersion" in buffered aqueous solvents make it suitable to study the effects of exogenous substances on its functionality. The RBCs responses to exogenous molecular stimuli, if properly evaluated, can clarify their intriguing and seemingly simple metabolism and, at the same time, they can also be profitably correlated at structurally more complex cells, such as neoplastic cells.

In this scenario, we have recently proposed an unprecedented erythrocyte-based biochemical approach focused on the metabolic similarity between cancer cells and RBCs to predict the antiproliferative effects of heterocyclic scaffolds [3]. Thus, we have investigated how the metabolic derangement of RBCs induced by DPIT $\left(2,2^{\prime}\right.$-dimethyl- $6,6^{\prime}$ diphenyl-6, $6^{\prime}, 7,7^{\prime}$-tetrahydro- $\mathrm{H}, 1^{\prime} \mathrm{H}-2,3^{\prime}$-biindole- $3,4,4^{\prime}(2 \mathrm{H}$, $5 \mathrm{H}, 5^{\prime} \mathrm{H}$ )-trione) (Figure 1), selected as an indole-based model compound, could be related to its antiproliferative effects $[4,5]$. With the aim to demonstrate the versatility and applicability of our approach, we herein further expand our studies focusing on PID (Figure 1), the chemical precursor of 


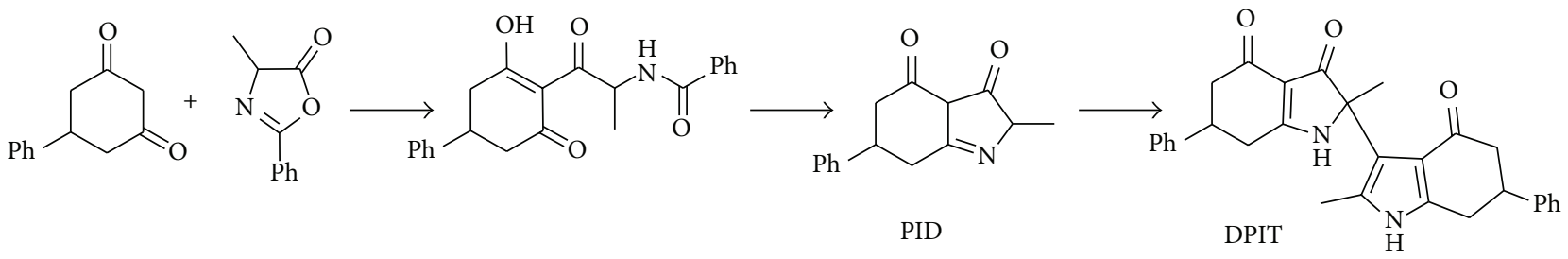

FIGURE 1: Multistep synthesis of PID.

DPIT. PID is an unprecedented indole-3,4-dione synthesized by some of us via one-pot acid-promoted $N$-deprotectioncyclization of the corresponding 1,3,3' -tricarbonyl precursor, powerful intermediate bearing an intriguing triketo Ytopology, the latter being obtained by microwave-mediated nucleophilic addition of 5-phenyl-1,3-cyclohexanedione to 4-methyl-2-phenyl-oxazol-5-one (Figure 1) [4, 6, 7]. Actually, our interest in the chemistry of both enolizable cyclic 1,3diketones and azlactones as building blocks for the synthesis of novel molecular architectures is well documented [4-15]. PID is a small weight heterocycle functionalized with the nitrogen analogue of the Y-triketo moiety, which could experience prototropic changes and bestows on it fascinating properties, such as an intrinsic stability and ability to act as bidentate chelating ligand.

Within our ongoing effort to propose new $\mathrm{N}, \mathrm{O}$-heterocycles with useful biological properties [7, 12-14], congeners of PID have been recently evaluated in vitro for antiviral activity against herpes simplex virus type-1 (HSV-1), resulting in lack of cytotoxicity and significant antiproliferative activity [7]. Nowadays we became interested in exploring the effect of PID on RBC functionalities, because we supposed that it could be able to cross the erythrocyte membrane, unlike its precursor, due to its smaller molecular weight, and consequently it could induce a pronounced metabolic derangement, one of whose most striking manifestations is the caspase 3 activation.

Caspase 3 belongs to a family of cysteine aspartate proteases responsible for degradation of cellular proteins and for the triggering of the apoptosis cell suicide program. It is a dormient proenzyme maintained in an inactive structural conformation, by an Asp-Asp-Asp regulatory tripeptide named "safety catch" [16]. This tripeptide is kept by in situ ionic interactions highly sensitive to $\mathrm{pH}$ that are disrupted by intracellular acidification, resulting in enhanced autocatalytic maturation of the protein that becomes more available to proteolytic activation. Resistance of caspase 3 activation plays a critical role in determining the sensitivity of cells to apoptosis and thus may contribute to the attenuated apoptosis observed in many cancers. Indeed, neoplastic cells have been shown to sequester caspase 3 in its inactive form, and thus, therapies that focus on activating caspase 3 are a promising novel anticancer strategy. The "safety catch" therefore is an important regulatory checkpoint that precludes the accidental activation of procaspase 3 in healthy cells having stable $\mathrm{pH}_{\mathrm{i}}$, while facilitating proteolytic activation of caspase 3 in damaged or stressed cells in which homeostatic maintenance of normal $\mathrm{pH}_{\mathrm{i}}$ is perturbed [16].
The primary cellular targets of caspase 3 are the cytoplasmic domain of the $\mathrm{B} 3$ (cdB3), the $\mathrm{Na}^{+} / \mathrm{H}^{+}$exchanger (NHE1), and the 4 plasma membrane $\mathrm{Ca}^{2+}$-ATPase (PMCA4) [17-19]. As it is known, cdB3 has several functions as the maintenance of anion homeostasis, the cytoskeleton cell shape, and the regulation of the metabolic glucose 6 phosphate pathways. In detail, cdB3 competitively binds both hemoglobin ( $\mathrm{Hb})$ and a number of glycolytic enzymes (GE). The cleavage of cdB3 induced by caspase 3 activation causes a preferential channeling of glucose 6 phosphate (G6P) in the EmbdenMeyerhof pathway (EMP) at the expense of the pentose phosphate pathway (PPP). Consequently both the increased lactate production by EMP and the lack of NADPH lead to cytosolic acidification and increase of oxidative stress [20].

NHE1 is a member of a family of electroneutral exchangers ubiquitously expressed that play an essential role in the regulation of $\mathrm{pH}_{\mathrm{i}}$, protection against cytosolic acidification, and absorption of $\mathrm{HCO}_{3}{ }^{-}$[21]. NHE1, activated by a decrease in $\mathrm{pH}_{\mathrm{i}}$, mediates the exchange of intracellular $\mathrm{H}^{+}$with extracellular $\mathrm{Na}^{+}$, while $\mathrm{HCO}_{3}{ }^{-}$comes out from $\mathrm{B} 3$ in exchange for $\mathrm{Cl}^{-}$. NHE could be affected by numerous endogenous and exogenous stimuli and in diverse pathological situations; it has also been shown to play an important role in the proliferation disorders $[22,23]$.

Taking into account that intracellular alkalinization is a common feature of proliferative processes [24], Izumi et al. rightfully proposed that the induction of intracellular acidification using, for example, pharmacological inhibitors of the NHE might serve as a therapeutic tool for treating some types of cancer [25].

Pászty et al. identified an additional cleavage target of caspase 3 on the PMCA, a calmodulin-regulated $\mathrm{Ca}^{2+}$ pump driven by ATP expressed in the plasma membrane of all eukaryotic cells [19]. Among the multiple isoforms of PMCA, 1 and 4 are typical of RBCs [26]. PMCA4 cleavage causes irreversible activation of the $\mathrm{Ca}^{2+}$ transport activity of the enzyme [27]. Several studies have suggested that changes in intracellular $\mathrm{Ca}^{2+}$ homeostasis play an important role in apoptosis $[28,29]$. Indeed, the primary switch in the decision between necrosis and apoptosis depends on various factors, including the intensity of the insult, the degree of the initial $\mathrm{Ca}^{2+}$ overload, and the intracellular ATP levels [30]. Deregulated apoptosis has been implicated in the development of many pathologic conditions, including neurodegenerative disorders, autoimmune diseases, sepsis, and particularly cancer $[31,32]$. In this context, it is now widely acknowledged that evasion of apoptosis is one of the hallmarks of cancer development, and naturally, this discovery has led to a diverse 
array of scientific explorations to identify drug targets and develop compounds that might effectively treat cancer through restoration of the apoptotic program [33-36].

Altogether these considerations prompted us to investigate the influence of PID on RBC functionalities, with particular reference to caspase activation, B3, oxidative state, intracellular ATP concentration and transport, metabolism, intracellular $\mathrm{pH}$, and $\mathrm{Ca}^{2+}$ homeostasis with the aim to point out that the metabolic derangements induced in RBC by PID would be unfavorable to the life cycle of neoplastic cells.

\section{Materials and Methods}

2.1. Reagents and Compounds. All reagents were purchased from Sigma-Aldrich (St. Louis, MO, USA). Citrate fresh human blood was obtained from informed healthy donors who declared that they had abstained from all drug treatment for at least one week prior to sample collection, in accordance with the principles outlined in the Declaration of Helsinki. Concentrated stock solution was prepared by dissolving PID in dimethyl sulfoxide (DMSO). PID was synthesized as previously described [4].

2.2. Preparation of Erythrocytes. Citrate blood samples were washed three times with an isoosmotic $\mathrm{NaCl}$ solution and treated as previously reported [37].

\subsection{High Performance Liquid Chromatography (HPLC)} Determinations. Washed RBCs were incubated at $37^{\circ} \mathrm{C}$ for $2 \mathrm{~h}$ with PID $(100 \mu \mathrm{M})$ in the incubation buffer $(35 \mathrm{mM}$ $\mathrm{Na}_{2} \mathrm{SO}_{4}, 90 \mathrm{mM} \mathrm{NaCl}, 25 \mathrm{mM}$ HEPES [N-(2-hydroxyethyl)piperazine- $\mathrm{N}^{\prime}$-2-ethanesulfonic acid], and $1.5 \mathrm{mM} \mathrm{MgCl}_{2}$ ), adjusted to $\mathrm{pH}$ 7.4. Samples were washed and the packed cells were lysed with $10 \%$ ethanol. Lysates were centrifuged at $4000 \times \mathrm{g}$ for $10 \mathrm{~min}$ at $4^{\circ} \mathrm{C}$ and the supernatant was filtered with $0.45 \mu \mathrm{m}$ filter. Free PID was analyzed by HPLC with a Shimadzu system, consisting of an LC-10AD pomp system and an SPDM10A diode array detector, a Rheodyne $7725 \mathrm{i}$ injector with a $20 \mu \mathrm{L}$ sample loop, and a reverse-phase Supelco C18 column $(5 \mathrm{~mm}, 250 \times 4.6 \mathrm{~mm})$. The mobile phase consisted of a linear gradient of acetonitrile in $\mathrm{H}_{2} \mathrm{O}$ as follows: $5-20 \%$ (0-2 min), $20-30 \%$ (2-4 min), 30-100\% (4$7 \mathrm{~min}$ ), and $100 \%(7-10 \mathrm{~min})$. The flow rate was $1.0 \mathrm{~mL} / \mathrm{min}$ at $25^{\circ} \mathrm{C}$. PID was detected at $286 \mathrm{~nm}$ and determined by comparison of peak areas with a standard solution of PID $(100 \mu \mathrm{M})$. To establish the amount of PID in the membrane bilayer, we induced RBCs hemolysis with hypotonic shock and centrifuged the samples at $15000 \mathrm{rpm}$ for $15 \mathrm{~min}$ at $4^{\circ} \mathrm{C}$. The supernatant was removed and the packed membrane structures were washed and centrifuged, as described above, three times with isoosmotic $\mathrm{NaCl}$ solution to eliminate the unbounded compound. After that, the packed membranes were treated with DMSO for $2 \mathrm{~h}$ and analyzed by HPLC to identify and quantify PID.

2.4. Binding to $\mathrm{Hb}$. Purified $\mathrm{Hb}(0.7 \mathrm{mg} / \mathrm{mL})$ in the $\mathrm{T}$ or $\mathrm{R}$ state was incubated for $1 \mathrm{~h}$ at $37^{\circ} \mathrm{C}$ in $0.1 \mathrm{M}$ HEPES buffer plus $0.1 \mathrm{M} \mathrm{NaCl}$ with PID $(100 \mu \mathrm{M})$ and $0.3 \mathrm{M} 2,3-$ biphosphoglyceric acid at $\mathrm{pH}$ 7.4. The free PID has been separated from the one bound to hemoglobin utilizing Microcon YM 30 (Nominal Molecular Weight Limit 30,000), filtered with $0.45 \mu \mathrm{m}$ filter, and analyzed by HPLC as described above.

2.5. Met-Hemoglobin (Met-Hb) Determination. Washed RBCs were treated with PID $(100 \mu \mathrm{M})$, at different incubation times from 6 to $24 \mathrm{~h}$, lysed with distilled water and freezing at $-20^{\circ} \mathrm{C}$, and then centrifuged at $18000 \mathrm{rpm}$ for $30 \mathrm{~min}$. The percentage of met-Hb was determined spectrophotometrically in a range of wavelength from 500 to $680 \mathrm{~nm}$.

2.6. Metal Chelating Activity. The chelation of $\mathrm{Fe}^{2+}$ by PID $(0-100 \mu \mathrm{M})$ was estimated by method of Dinis et al. [38]. The percentage inhibition of ferrozine- $\mathrm{Fe}^{2+}$ complex formation was calculated as $\left[\left(A_{0}-A_{s}\right) / A_{0}\right] \times 100$, where $A_{0}$ was the absorbance of the control and $A_{s}$ was the absorbance of the samples in the presence of PID (562 nm).

2.7. Band 3 Anion Exchanger Activity Determination: Sulphate Transport Measurement. Cells were incubated in the incubation buffer containing sulphate at $25^{\circ} \mathrm{C}$, in the presence and absence of PID $(100 \mu \mathrm{M})$. At specified intervals $10 \mu \mathrm{mol}$ of 4 -acetamido- $4^{\prime}$-isothiocyanostilbene- $2,2^{\prime}$-disulfonic acid (SITS) stopping medium was added to each test tube containing the RBC suspension. Cells were separated from the incubation medium by centrifugation (J2-HS Centrifuge, Beckman, Palo Alto, CA, USA) and washed three times at $4^{\circ} \mathrm{C}$ with a sulphate-free medium. After the final washing, the packed cells were lysed with perchloric acid (4\%) and distilled water and centrifuged at $4^{\circ} \mathrm{C}$. Sulphate ions in the supernatant were precipitated by adding glycerol and distilled water $(1: 1), 4 \mathrm{M}$ $\mathrm{NaCl}$ and $1 \mathrm{M} \mathrm{HCl}$ solution, and $1.23 \mathrm{M} \mathrm{BaCl}_{2} \cdot 2 \mathrm{H}_{2} \mathrm{O}$ to obtain a homogeneous barium sulphate precipitate. The intracellular sulphate concentration was measured by spectrophotometry at $425 \mathrm{~nm}$ wavelength as reported previously [39].

2.8. Determination of Phosphatase PTP-1B Activity. Cells were incubated in the incubation buffer at $37^{\circ} \mathrm{C}$ in the presence and absence of PID $(100 \mu \mathrm{M})$ and treated as previously reported [40].

2.9. Effects on Superoxide Anion Generation. Superoxide anions were measured as previously reported [41].

2.10. Reduced Glutathione (GSH) Measurements. GSH was analyzed in haemolysate using the Ellman method [42]. The samples were treated with trichloroacetic acid (TCA) and the protein precipitate was removed by centrifugation. The concentration of GSH was estimated in $\mathrm{mmol} /$ packed cells (PC).

2.11. Total Thiols Measurements. The content of the total thiols was measured using the method of Ellman [42]. Samples were diluted with a $20 \mathrm{mmol} / \mathrm{L}$ phosphate buffer, 
$\mathrm{pH}$ 8.0, containing SDS. Following this, DTNB (5, $5^{\prime}$-dithiobis (2-nitrobenzoic acid)) from a $10 \mathrm{mmol} / \mathrm{L}$ stock solution was added and samples were incubated for $1 \mathrm{~h}$ at $37^{\circ} \mathrm{C}$. The thiols reacted with DTNB to form anions with a strong yellow color which were optically active at $412 \mathrm{~nm}$. The basal optical activity of the samples was measured before the addition of DTNB. A calibration curve was prepared using different concentrations of GSH. The concentration of the thiol groups was calculated and expressed as $\mu \mathrm{mol} / \mathrm{mg}$ proteins of plasma or as $\mathrm{nmol} / \mathrm{mg}$ proteins of RBC membranes.

2.12. Glutathione Peroxidase (GPx) Analysis. GPx activity inside the RBC was analyzed by a commercial kit (Glutathione Peroxidase Cellular Activity Assay Kit, SigmaAldrich) following the instruction supplied by the seller.

2.13. Lipid Peroxidation Assay. Isolated RBCs were incubated for $2 \mathrm{~h}$ in the absence or in the presence of PID $(25,50$, and $100 \mu \mathrm{M})$ and analyzed as previously described [3].

2.14. Acetylcholinesterase (AChE) Enzyme Assay. AChE activity was assayed in RBCs suspensions after PID $(100 \mu \mathrm{M})$ treatment using the colorimetric method proposed by Ellman et al. [43].

2.15. Measurement of Percentage Haemolysis. The haemolysis of RBCs was determined spectrophotometrically at $576 \mathrm{~nm}$ based on the ratio of $\mathrm{Hb}$ released from cells to the total cellular $\mathrm{Hb}$ content after haemolysis with distilled water. The ratio of haemolysis was calculated from the following equation: $H(\%)=A_{1} / A_{2} \times 100 \%$, where $H(\%)$ is the percent of haemolysis of the RBCs, $A_{1}$ is the absorbance of the supernatants of the samples of the RBCs incubated with or without PID $(100 \mu \mathrm{M})$, and $A_{2}$ is the absorbance of the supernatant of the samples after complete haemolysis with distilled water.

2.16. Caspase 3 Assay. Citrate blood samples were washed three times with an isoosmotic $\mathrm{NaCl}$ solution and treated as previously reported [41], using PID $(50 \mu \mathrm{M})$ and tert-butylhydroperoxide (t-BHT), $100 \mu \mathrm{M}$.

2.17. $\mathrm{pH}_{\mathrm{i}}$ Measurement. Isolated RBCs were incubated from 2 to $24 \mathrm{~h}$ in the absence or in the presence of PID $(100 \mu \mathrm{M})$. After incubation, the samples were washed 3 times with 10 volumes of isoosmotic $\mathrm{NaCl}$ and lysed by treatment with ice distilled water, vortex, and ultrasonication. Then the samples were centrifuged and the $\mathrm{pH}_{\mathrm{i}}$ was measured using a $\mathrm{pH}$ meter ProLab 3000 Schott.

2.18. Annexin V Apoptosis Detection. Fluorescence-activated cell sorting (FACS) analysis was performed as described by Andree et al. [44]. RBCs were incubated for 6, 12, and $24 \mathrm{~h}$ in the presence or absence of PID $(100 \mu \mathrm{M})$ in annexin-binding buffer containing $0.14 \mathrm{M} \mathrm{NaCl}, 0.01 \mathrm{M}$ HEPES-NaOH $(\mathrm{pH}$ 7.4 ), and $2.5 \mathrm{mM} \mathrm{CaCl}_{2}$. RBCs were suspended in a solution composed of Annexin-V-Fluos and annexin buffer. After
10 min of incubation in the dark, samples were finally diluted 1:5 in annexin-binding buffer and measured using flow cytometric analysis. Cells were analyzed by forward scatter, and annexin fluorescence intensity was measured in fluorescence channel FL-1 with an excitation wavelength of $488 \mathrm{~nm}$ and an emission wavelength of $530 \mathrm{~nm}$.

2.19. Measurement of Intra-/Extracellular $\mathrm{Ca}^{2+}$. Isolated RBCs were incubated for 2 and $6 \mathrm{~h}$ in the absence or in the presence of PID $(100 \mu \mathrm{M})$. After incubation, the samples were washed 3 times with 10 volumes of isoosmotic $\mathrm{NaCl}$ and centrifuged at $2500 \mathrm{rpm}$ for $5 \mathrm{~min}$. Then, intra-/extracellular $\mathrm{Ca}^{2+}$ concentration was analyzed by a commercial kit (Calcium Colorimeric Assay Kit, Sigma-Aldrich) following the instruction supplied by the seller.

2.20. Measurement of Intra-/Extracellular ATP. ATP was measured by the luciferin-luciferase technique, as previously reported [45].

2.21. Statistical Analysis. Data are presented as mean of four different experiments \pm standard deviation (SD). The data were analyzed by one-way analysis of variance. The significance of the differences in relation to the respective controls for each experimental test condition was calculated by Student's $t$-test for each paired experiment. A $P$ value of $<0.05$ versus control was regarded as significant difference and indicated with asterisks in the figures.

\section{Results and Discussion}

3.1. PID Crosses the RBC Membrane. HPLC observations of RBCs incubated with PID $(100 \mu \mathrm{M})$ at $37^{\circ} \mathrm{C}$ for $2 \mathrm{~h}$ reveal that PID crosses the $\mathrm{RBC}$ membrane reaching inside of the cell a $20 \%$ share (Figure 2). The different molecular weight could probably explain the greater ability of PID to cross the plasma membrane, localizing in the cytosol, with respect to the precursor DPIT. According to our previous reports [36, $40,41,46,47]$, we can extrapolate that exogenous compounds permeate more easily through the RBC membrane within the molecular weight range $200-300 \mathrm{~g} / \mathrm{mol}$.

3.2. PID Does Not Bind Hb but Increases the B3 Protein Exchange. Since $\mathrm{Hb}$ and $\mathrm{B} 3$ are the two most abundant RBC proteins, inside the cytoplasm and in the membrane, respectively, the effects of PID on their structure and functionality were explored.

To this end, purified $\mathrm{Hb}$ was incubated with PID $(100 \mu \mathrm{M})$ for $1 \mathrm{~h}$ at $37^{\circ} \mathrm{C}$ and the levels of free PID were assessed by HPLC, excluding PID-Hb interaction (data not shown). Furthermore it does not affect the $\mathrm{Hb}$ redox reactions because no increased values of met-Hb were registered incubating RBCs with PID $(100 \mu \mathrm{M})$ for 6-12-24h (data not shown). Additionally, the inability of PID to chelate $\mathrm{Fe}^{2+}$ was demonstrated by UV-vis spectroscopy.

The influence of PID on B3 was studied evaluating spectrophotometrically its effect on anion exchanger functionality after pretreatment of RBCs with PID $(100 \mu \mathrm{M})$ and 


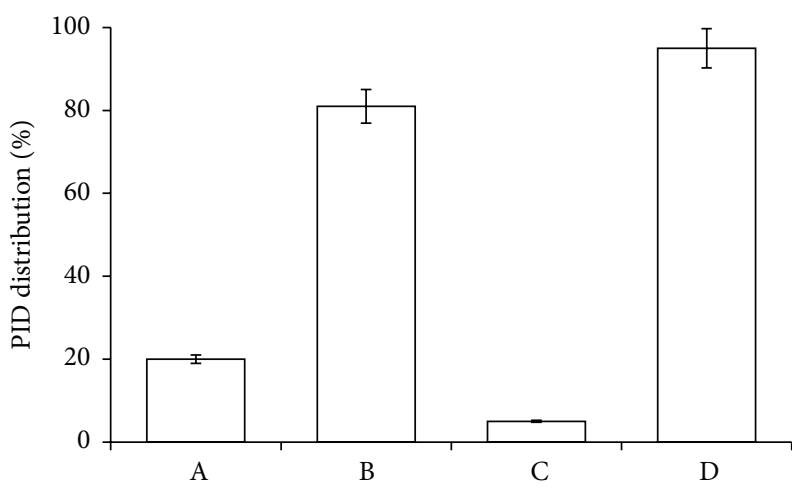

FIGURE 2: HPLC determination: PID distribution inside (A), outside (B), and in the RBC membrane (C), compared to the control (PID $100 \mu \mathrm{M}$ standard solution (D)).

comparing the results with the control. Figure 3(a) shows an increase of anion exchange of about $30 \%$ in the presence of PID (rate constant: 0.017 and $0.012 \mathrm{~min}^{-1}$ in RBCs incubated with and without PID, resp.).

The derangement of $\mathrm{B} 3$ function, being one of the main causes of the $\mathrm{pH}_{\mathrm{i}}$ decrease, could act as a factor which creates an "acidic environment" for organ cells. Since $\mathrm{pH}_{\mathrm{i}}$ has been shown to be alkaline in many human cancer cells and to be an important trigger for cell proliferation [24], PID influence on B3 functionality could contribute to inhibiting cell proliferation and leading the tumor cells to be more sensitive to antitumor drug. Also the fact that B3 interacts with and regulates the function of p16, a key negative regulating protein for the cell cycle [48], is not to be underestimated. In this context Shen et al. demonstrated that B3 plays a crucial role in the pathogenesis of gastric and colonic adenocarcinoma and that p16 dysfunction is a novel pathway of carcinogenesis [49]. To find potential justification for PID-induced destabilization on B3 physiological exchange, we tested the tyrosine phosphatase activity as an index of phosphorylation state of RBC (Figure 3(b)). It is noteworthy that changes in phosphorylation are among the most important modulations of protein activity in RBCs [50]. In particular, the delicate balance between phosphorylation and dephosphorylation on RBC membrane depends on the action of two types of proteins, tyrosine phosphatases (PTP1B) and src tyrosine kinases that are strongly influenced by free radical concentration [51].

Thus, the PTP1B activity was tested in the presence of PID $(100 \mu \mathrm{M})$ or orthovanadate (OV), a known phosphatase inhibitor. Results shown in Figure 3(b) highlighted that PID induced hyperactivation of phosphatases (about 30\%) in comparison to the control, clearly indicating an alteration of RBC phosphorylation balance.

The phosphorylation and consequent inhibition of the pyruvate dehydrogenase complex (PDC) would contribute to the Warburg metabolic correlated with malignant progression of cancer cells [52]. Taking into account the metabolic similarities between RBCs and cancer cells that we have recently proposed [3], we can speculate that the correction of this metabolic abnormality could offer opportunities for cancer treatment and may potentially synergize with other cancer therapies.

3.3. PID Influences the RBC Oxidative State. The influence of PID on the redox equilibrium of the RBCs was evaluated in terms of superoxide generation, GSH levels, GPx activity, thiol redox status, and lipid peroxidation. The rate of superoxide generation was analyzed in vitro at different concentrations $(10,25,50$, and $100 \mu \mathrm{M})$, resulting in the fact that PID triggered superoxide generation at $50 \mu \mathrm{M}$ and more evidently at $100 \mu \mathrm{M}$ (Figure 4).

GSH is a principal intracellular thiol-containing compound and it is involved in maintaining the oxidationreducing balance in RBCs. Therefore GSH concentration and thiol redox status have been evaluated in RBCs pretreated with PID $(100 \mu \mathrm{M})$. Figure 5 shows the depletion of GSH (a) and the decrease of - $\mathrm{SH}$ groups (b), in comparison to the control. Furthermore, the GPx activity was also tested, showing that PID does not alter the enzyme functionality (data not shown).

Oxidation of -SH groups is strictly related with lipid oxidation of the membrane. Then peroxidation was evaluated on the RBC membrane after incubation for $2 \mathrm{~h}$ with PID (2550-100 $\mu \mathrm{M})$. Unexpectedly a slight inhibition at the higher concentration was observed, compared with the control (Figure 6), likely due to the ability of PID to break the lipid peroxidation chain reaction.

Such considerations are further supported by the evaluation of the integrity of plasma membrane assessed monitoring the functionality of AChE, a well-known marker of cell membrane wholeness, resulting in the fact that PID (0$100 \mu \mathrm{M})$ did not significantly modify the enzyme activity (data not shown). Moreover, it did not increase the percentage of haemolysis.

Based on the experimental evidences, we assume that PID shifts the RBCs towards an oxidative state, increasing the generation of superoxide and the oxidation of thiol groups. Additionally, reduced GSH levels are detected, leading to dangerous oxidant/antioxidant imbalance and to an increase of intracellular $\mathrm{H}_{2} \mathrm{O}_{2}$. Indeed $\mathrm{GSH}$, through the action of GPx, catalytically detoxifies the cells from peroxides such as $\mathrm{H}_{2} \mathrm{O}_{2}$. So the GSH depletion always causes accumulation of reactive oxygen species (ROS) and consequently intracellular acidification $[24,53]$.

3.4. PID Influences Caspase 3 Activation and $p H_{i}$. Generally, the increase of the oxidative stress and the decrease of $\mathrm{pH}$ significantly contribute to the direct activation of caspase 3 by removal of the "safety catch" $[16,54-56]$. To confirm the above, RBCs were incubated, respectively, in the absence and in the presence of PID $(50 \mu \mathrm{M})$ or t-BHT $(100 \mu \mathrm{M})$ as a reference oxidant. Figure 7 shows that PID significantly induces caspase 3 activation, even superior to t-BHT.

Generally, caspase 3 activation leads to inappropriate triggering or rapid disablement of key structural proteins and important signaling, homeostatic and repair enzymes [57]. In nucleate cells, caspase 3 processing occurs in a protease cascade involving mitochondrial release of cytochrome $\mathrm{c}$ in the 


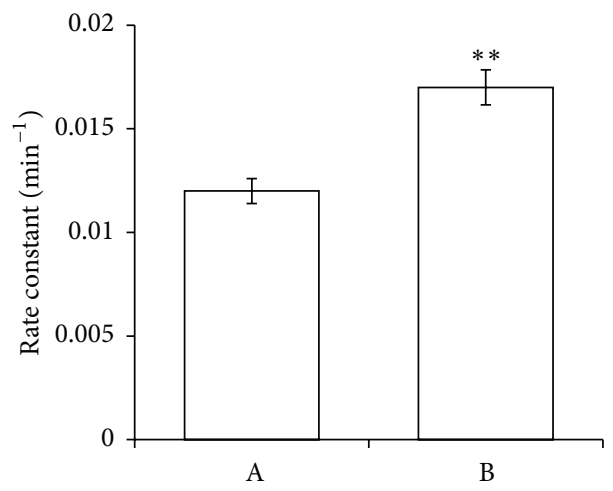

(a)

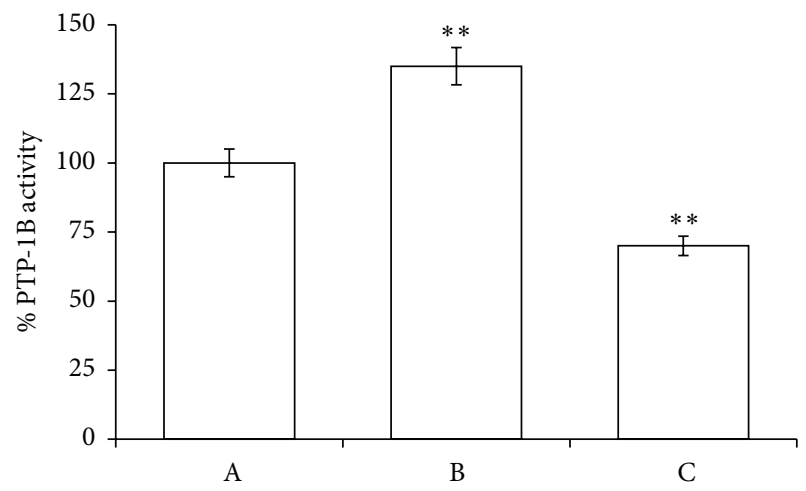

(b)

FIGURE 3: Effects of PID on rates of sulphate transport (a) and on phosphatase activity (b) in normal human RBCs, incubated in absence (A) or in the presence of $100 \mathrm{PID} \mu \mathrm{M}$ (B) or OV $1.0 \mathrm{mM}$ (C). Results are from four independent experiments \pm standard deviation. Asterisks indicate significant differences at $P<0.05$ versus control.

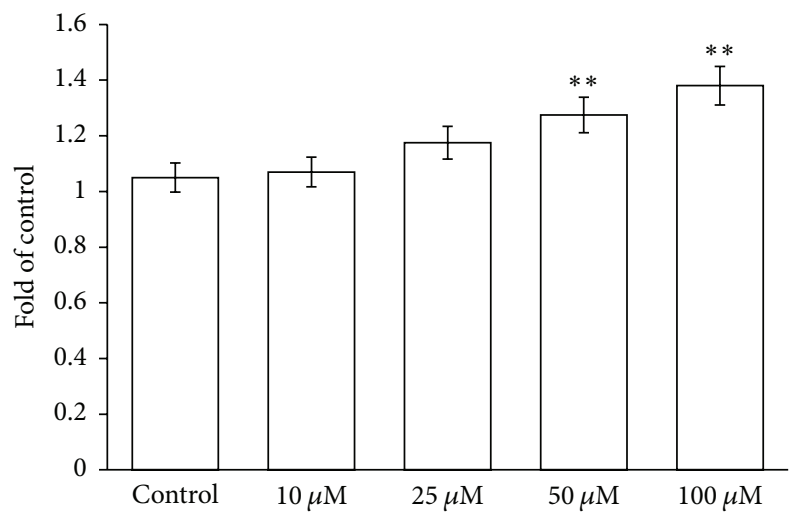

FIGURE 4: Effects of PID $(0-100 \mu \mathrm{M})$ on superoxide anion radical generation. Results are from four independent experiments \pm standard deviation. Asterisks indicate significant differences at $P<$ 0.05 versus control.

cytosol, while in RBCs, in the absence of mitochondria and cytochrome $c$, this mechanism appears to operate directly. Caspase 3 catalyzes the specific cleavage of cdB3, NHE1, and PMCA4. The cdB3 and NHE1 cleavage contributes to the alteration of the hydrogen ions concentration, as $\mathrm{HCO}_{3}{ }^{-} / \mathrm{Cl}^{-}$ exchange occurs in conjugation with the $\mathrm{Na}^{+} / \mathrm{H}^{+}$antiporter [18]. The hyperstimulation of the B3 induced by PID should be offset by the NHE1 activity to maintain the correct $\mathrm{pH}$ homeostasis. However, caspase 3 activation results in NHE1 inhibition and reduced $\mathrm{Na}^{+} / \mathrm{H}^{+}$antiporter activity acidifies cells $[18,58]$. Therefore, PID would change the $\mathrm{pH}_{\mathrm{i}}$ of RBCs inducing cytosolic acidification, according to literature [59]. To confirm the above, $\mathrm{pH}_{\mathrm{i}}$ was measured by incubating $\mathrm{RBCs}$ in the presence of PID $(100 \mu \mathrm{M})$, resulting in a decrease of 0.1 units. Literature data have recently reported that intracellular acidification in mammalian cells, typically amounting to 0.3-0.4 $\mathrm{pH}_{\mathrm{i}}$ units, can be detected following exposure of cells to external stimuli as UV irradiation, staurosporine, and etoposide [24]. Our experimental observation, namely, a variation of $0.1 \mathrm{pH}_{\mathrm{i}}$ units could be related to the presence in RBCs of a high concentration of $\mathrm{Hb}$ that can buffer a more pronounced cytosolic acidification. Indeed, $\mathrm{Hb}$, at a concentration of 7 mmoles per litre of cell water, is the RBC's main proton buffer [60].

Furthermore, within the last decade, numerous studies have demonstrated that $\mathrm{pH}_{\mathrm{i}}$ homeostasis is often dramatically altered in cancer cells, as they maintain a $\mathrm{pH}_{\mathrm{i}}$ more alkaline than their normal counterparts [61]. This has sparked substantial interest in $\mathrm{pH}$ regulation as a potential therapeutic target relevant to many forms of cancers [62]. In particular, regulation of $\mathrm{pH}_{\mathrm{i}}$ may be a possible mechanism for tumorselective therapy. Rightfully, it has even been proposed that the induction of an intracellular acidification, using, for example, pharmacological inhibitors of the NHE, might serve as a therapeutic tool for treating some types of cancer. In this context, we postulate that PID may determine in cancer cells a more pronounced cytosolic acidification with respect to that observed in our "buffered" erythrocyte-based model of study, providing a way of inducing tumor-specific apoptosis, thus aiding cancer chemotherapy.

3.5. PID Influences Intracellular $\mathrm{Ca}^{2+}$ Homeostasis, ATP Efflux, and $\mathrm{RBC}$ Metabolism. Generally, a decrease in $\mathrm{pH}_{\mathrm{i}}$ is the initial trigger for a cascade of events resulting in apoptosis [25]. Indeed, acidification facilitates the caspase 3 activation by removal of the "safety catch", that in turn has been shown to induce phosphatidylserine (PS) exposure [63]. In normal RBCs, plasma membranes exhibit significant phospholipid asymmetry, with phosphatidylcholine and sphingomyelin predominantly on the external side and phosphatidylethanolamine and PS on the inner side. Entry into apoptosis leads to a loss of phospholipid asymmetry, with exposure of PS on the outer side. It was shown that the anticoagulant annexin $\mathrm{V}$ preferentially binds to negatively charged phospholipids like PS. Thus, this binding of annexin $\mathrm{V}$ was used to detect PS exposure on the membrane of apoptotic cells in cytofluorimetric assays (Figure 8). Our experiments were performed at 6,12 , and $24 \mathrm{~h}$, resulting in a $4.2 \%$ of apoptosis in the early phase $(6 \mathrm{~h})$, while at longer 


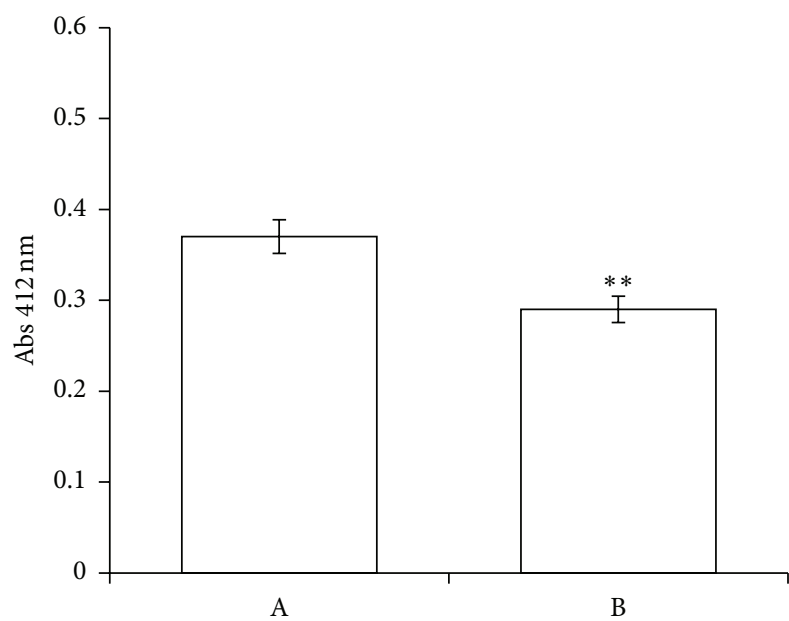

(a)

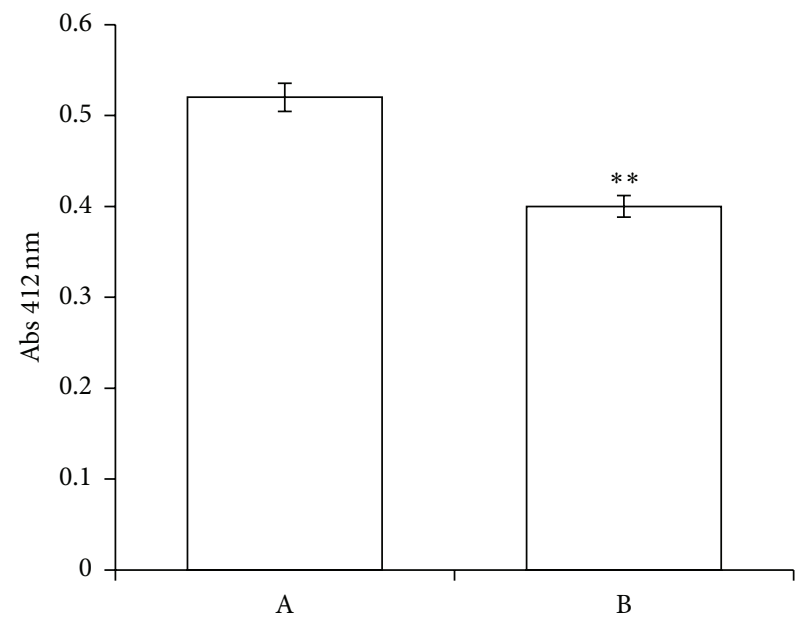

(b)

FIgURE 5: Influence of PID on intracellular levels of GSH (a) and total thiols (b). The RBCs were incubated for $2 \mathrm{~h}$ in absence (A) or in the presence of PID $100 \mu \mathrm{M}$ (B). Results are from four independent experiments \pm standard deviation. Asterisks indicate significant differences at $P<0.05$ versus control.

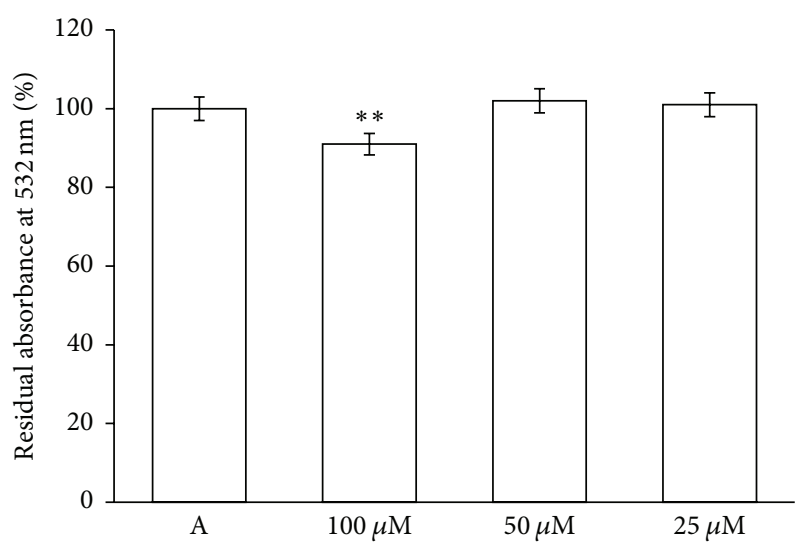

FIGURE 6: Influence of PID on lipid peroxidation of RBC membrane. The RBCs were incubated for $2 \mathrm{~h}$ in absence (A) or in the presence of PID $(25-100 \mu \mathrm{M})$. Results are from four independent experiments \pm standard deviation. Asterisks indicate significant differences at $P<$ 0.05 versus control.

incubation periods the intensity of the apoptotic process increases ( $4.8 \%$ at $12 \mathrm{~h} ; 8.2 \%$ at $24 \mathrm{~h}$ ).

Triggers of apoptosis include exposure to several stressors such as oxidative stress, NHE inhibitors, cytosolic acidification, and increase of cytosolic $\mathrm{Ca}^{2+}$ levels [64]. In this regard, the effects of PID $(100 \mu \mathrm{M})$ on the calcium-permeable channels PMCA were evaluated at $2 \mathrm{~h}$ and $6 \mathrm{~h}$, showing a slight increase in the intracellular free $\mathrm{Ca}^{2+}$ levels (data not shown), in accordance with the low apoptotic effect observed.

The limiting factor of the PMCA transport capacity is ATP availability [50]. Indeed, both the $\mathrm{Ca}^{2+}$ homeostasis and the cellular ATP are important determinants of cell death. In particular, cells remain alive when certain level of ATP is maintained, but when ATP falls below this level, apoptosis

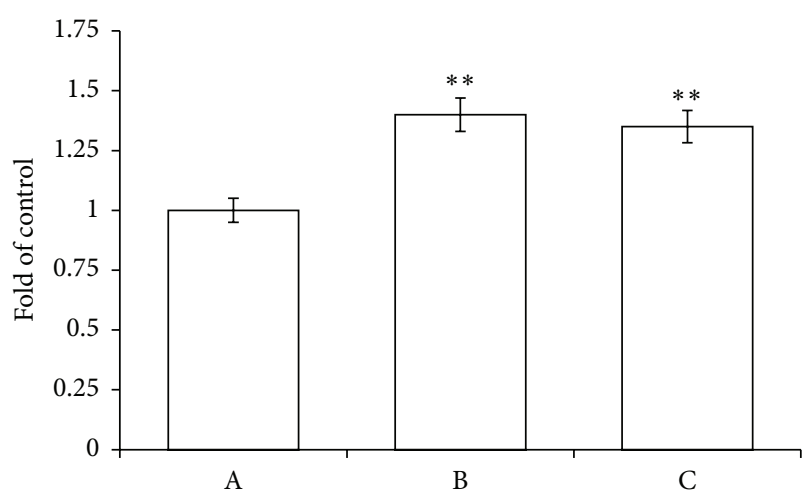

FIgURE 7: Caspase 3 activity in RBCs in the absence (A) and in the presence of PID $50 \mu \mathrm{M}$ (B) or t-BHT $100 \mu \mathrm{M}$ (C). Results are from four independent experiments \pm standard deviation. Asterisks indicate significant differences at $P<0.05$ versus control.

is activated, and a severe drop in cellular ATP causes cell necrosis [65]. Thus, the influence of PID on ATP release from RBCs was evaluated, showing that RBCs pretreated with PID $(100 \mu \mathrm{M})$ released significantly less ATP than in normal conditions, but the intracellular [ATP] does not appear affected by the treatment (Figure 9), although both the PMCA4 hyperactivity and the phosphatases triggering should deplete the cellular ATP.

We suggest that this condition could be related to an alteration of the metabolic modulation of RBCs attributable to PID influence. In particular, as $\mathrm{cdB} 3$ serves as a docking station for multiple GE, its cleavage operated by caspase 3 deprives RBCs of the fundamental and primary regulation of metabolic G6P pathways. Specifically, the predominant EMP is favored to produce ATP and NADH, at the expense of the PPP, only source of reducing power (NADPH). Cancer 

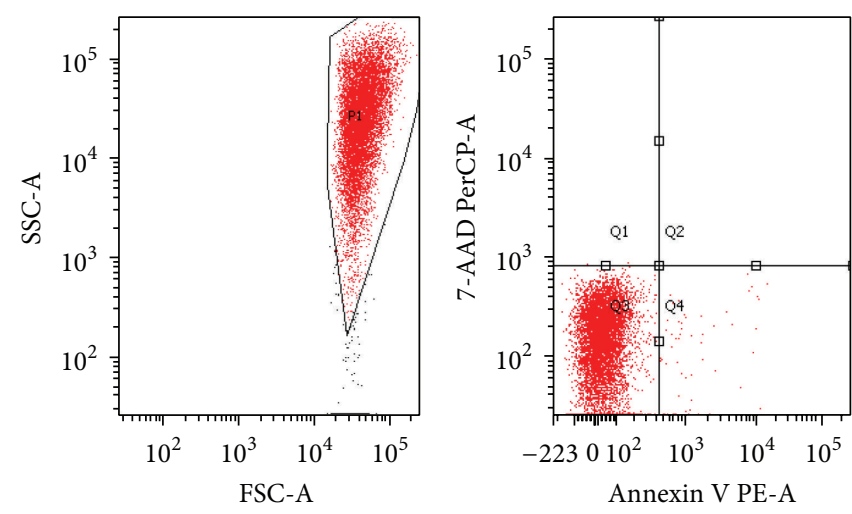

(a)
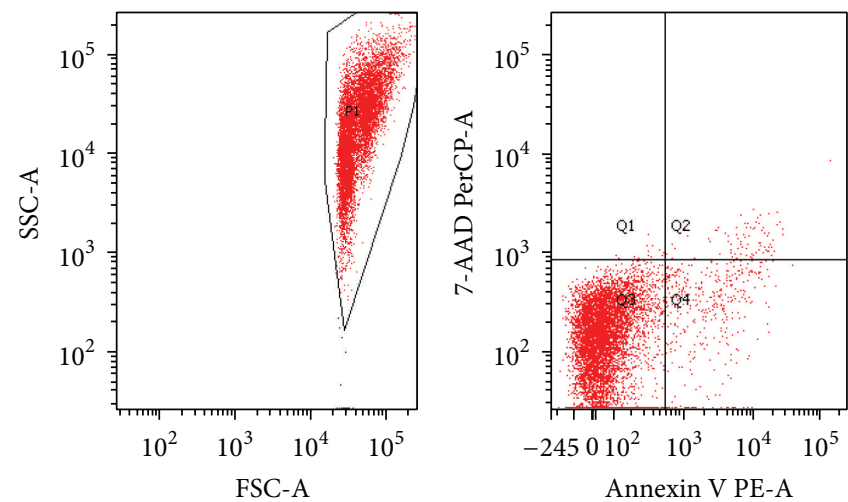

(c)
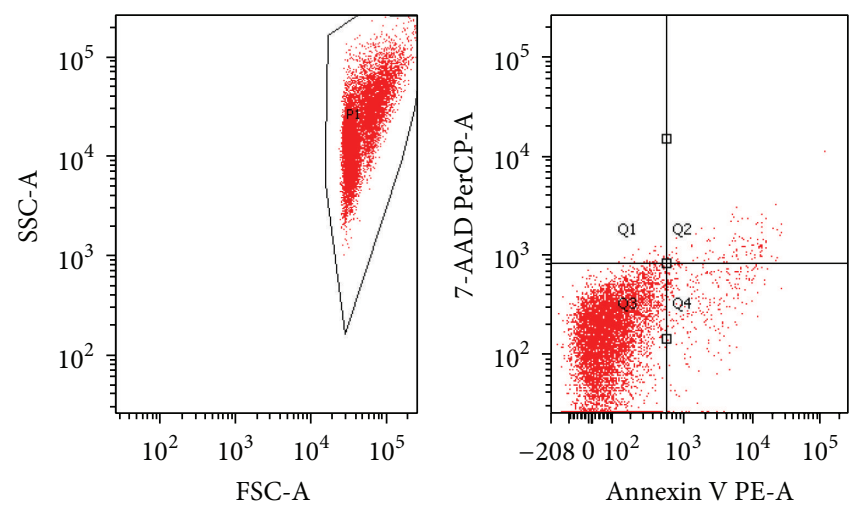

(b)
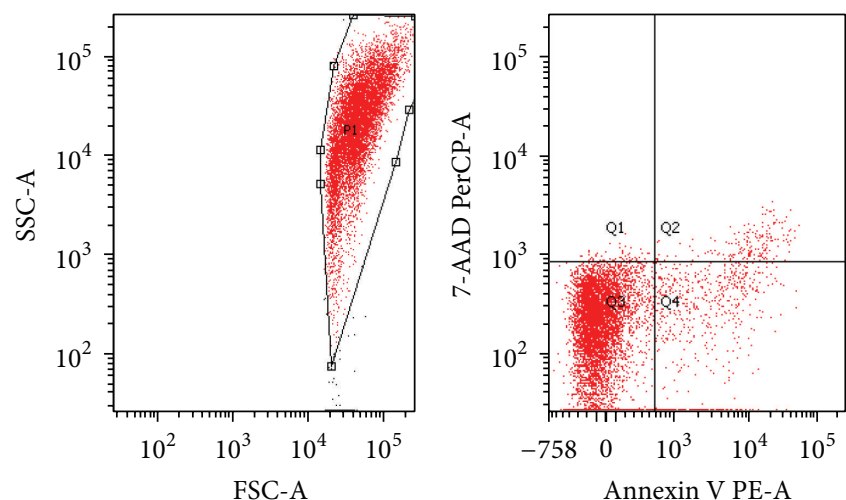

(d)

FIGURE 8: Flow cytometric analysis of apoptosis in RBC in the absence (a) and in the presence of PID (100 $\mu \mathrm{M})$ after $6 \mathrm{~h}(\mathrm{~b}), 12 \mathrm{~h}$ (c), and $24 \mathrm{~h}$ (d) of incubation time.

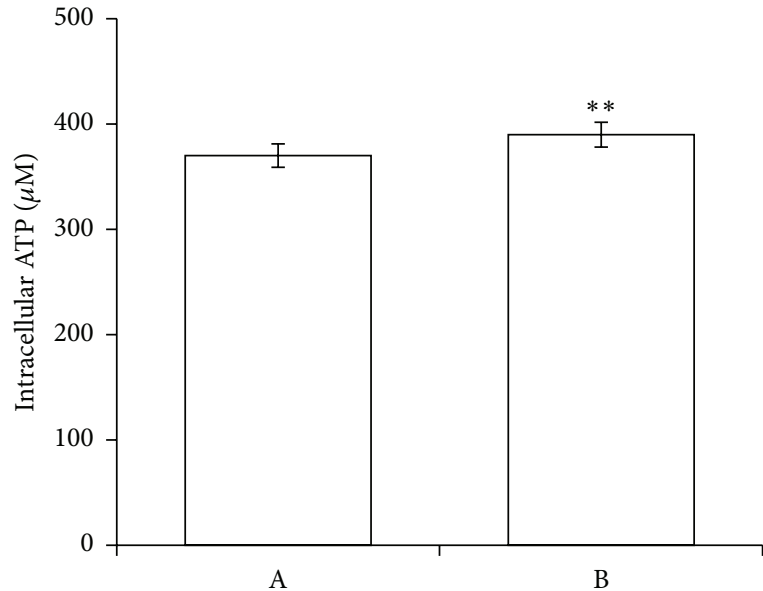

(a)

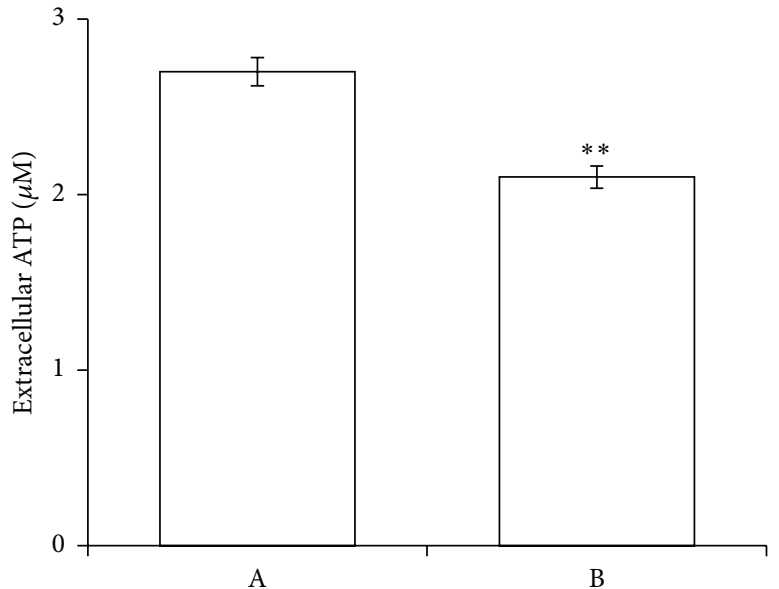

(b)

FIGURE 9: Effect of PID on the intracellular (a) and extracellular (b) ATP levels in RBCs. ATP concentrations were measured at the end of the incubation time of erythrocytes without (A) and with PID $100 \mu \mathrm{M}$ (B). Results are from four independent experiments \pm standard deviation. Asterisks indicate significant differences at $P<0.05$ versus control.

cells experience a substantial need of reducing power in the form of NADPH for the biosynthesis of lipids and nucleotides required during proliferation. In this context, PID would interfere with cell proliferation not only by reducing NADPH and GSH availability, but also by positively modulating the functionality of pyruvate kinase M2 (PKM2) isoform expressed in cancer cells with low activity [66].

In particular, both the EMP enhancement, with the wider availability of fructose 1,6 biphosphate, and the cytosolic acidification induced by PID would activate the PKM2. 


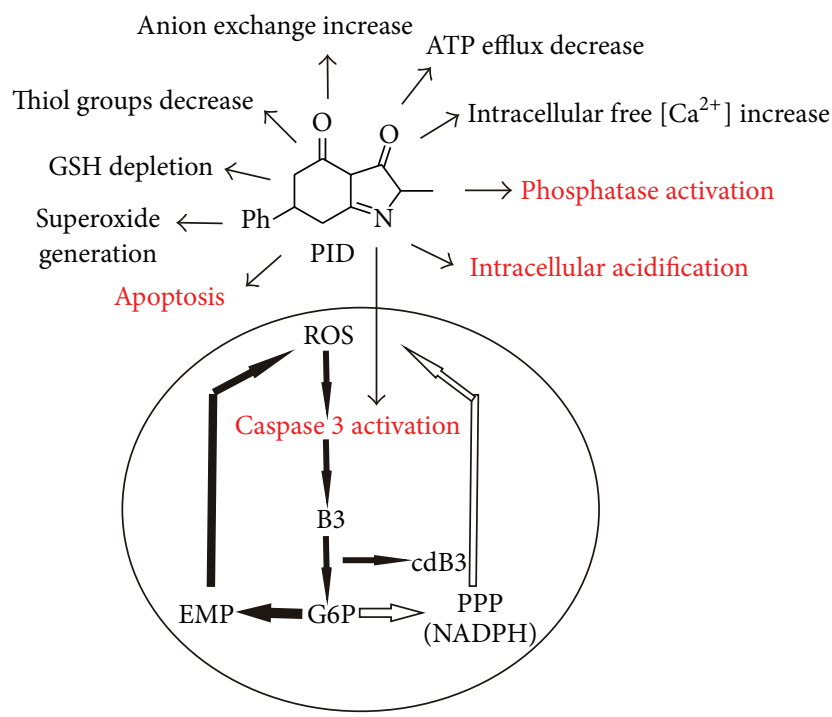

FIGURE 10: Effects of PID in RBCs and schematic representation of the "vicious circle" induced by PID. In red, the main antiproliferative conditions are highlighted.

Thus, the use of small molecule PKM2 activators may be an appropriate approach to interfere with cancer cell metabolism for therapeutic purposes.

In summary, this study contributes to highlighting the great potentiality of RBCs as versatile cellular model of study to predict the antiproliferative behaviour of selected heterocycles with different cellular localization. In particular, DPIT [3] is almost completely intercalated in the phospholipid bilayer, while PID crosses the RBC membrane. This different distribution leads to a series of complex metabolic responses that can be due to direct interactions/activations with cytosolic components and consequent increment of endogenous oxidative stress (i.e., PID) or to extracellular signals trigger that, on the whole, can culminate in the same increase of oxidative stress (i.e., DPIT). In particular, the effects of PID on RBCs, culminating in the caspase activation, would be represented in a "vicious circle" (Figure 10), in which the main antiproliferative conditions are highlighted.

\section{Competing Interests}

The authors declare that they have no competing interests regarding the contents of this paper.

\section{References}

[1] L. Douay and M.-C. Giarratana, "The cultured red blood cell: a study tool with therapeutic perspectives," Cell Cycle, vol. 4, no. 8, pp. 999-1000, 2005.

[2] N. Romero and R. Radi, "Hemoglobin and red blood cells as tools for studying peroxynitrite biochemistry," Methods in Enzymology, vol. 396, pp. 229-245, 2005.

[3] A. Scala, S. Ficarra, A. Russo et al., "A new erythrocyte-based biochemical approach to predict the antiproliferative effects of heterocyclic scaffolds: the case of indolone," Biochimica et
Biophysica Acta-General Subjects, vol. 1850, no. 1, pp. 73-79, 2015.

[4] A. Scala, M. Cordaro, A. Mazzaglia et al., "Aldol-type compounds from water-soluble indole-3,4-diones: synthesis, kinetics, and antiviral properties," Molecular Diversity, vol. 17, no. 3, pp. 479-488, 2013.

[5] A. Rescifina, A. Scala, M. T. Sciortino et al., "Decorated 6, $6^{\prime}, 7,7^{\prime}$-tetrahydro- $1 \mathrm{H}, 1^{\prime} \mathrm{H}-2,3^{\prime}$-biindole scaffold as promising candidate for recognition of the CDK2 allosteric site," MedChemComm, vol. 6, no. 2, pp. 311-318, 2015.

[6] M. Cordaro, G. Grassi, F. Risitano, and A. Scala, "A new construction of diversely functionalized oxazoles from enolizable cyclic 1,3-dicarbonyls and 5(4H)-oxazolones," Synlett, no. 1, pp. 103-105, 2009.

[7] A. Scala, M. Cordaro, A. Mazzaglia et al., "Synthesis and anti HSV-1 evaluation of novel indole-3,4-diones," MedChemComm, vol. 2, no. 3, pp. 172-175, 2011.

[8] E. Altieri, M. Cordaro, G. Grassi, F. Risitano, and A. Scala, "An improved diastereoselective synthesis of spiroazoles using multicomponent domino transformations," Synlett, vol. 14, pp. 2106-2108, 2010.

[9] M. Cordaro, G. Grassi, F. Risitano, and A. Scala, "N-Substituted and $\mathrm{N}$-unsubstituted 1,3-Oxazolium-5-olates cycloaddition reactions with 3-substituted coumarins," Tetrahedron, vol. 66, no. 14, pp. 2713-2717, 2010.

[10] M. Cordaro, G. Grassi, A. Rescifina, U. Chiacchio, F. Risitano, and A. Scala, "Stereodefined ring contraction-rearrangement of thiocoumarins to new fused benzo[b]thiophene derivatives," Tetrahedron, vol. 67, no. 3, pp. 608-611, 2011.

[11] M. Cordaro, F. Risitano, A. Scala, A. Rescifina, U. Chiacchio, and G. Grassi, "Self-catalyzed Mannich-type reaction of enolizable cyclic 1,3-dicarbonyls to acyclic nitrones: an entry to functionalized $\beta$-enamino diones," Journal of Organic Chemistry, vol. 78, no. 8, pp. 3972-3979, 2013.

[12] A. Scala, M. Cordaro, F. Risitano et al., "Diastereoselective multicomponent synthesis and anti-HSV-1 evaluation of dihydrofuran-fused derivatives," Molecular Diversity, vol. 16, no. 2, pp. 325-333, 2012.

[13] A. Scala, M. Cordaro, G. Grassi et al., "Direct synthesis of C3mono-functionalized oxindoles from $\mathrm{N}$-unprotected 2-oxindole and their antileishmanial activity," Bioorganic and Medicinal Chemistry, vol. 22, no. 3, pp. 1063-1069, 2014.

[14] A. Scala, A. Piperno, F. Risitano, S. Cirmi, M. Navarra, and G. Grassi, "Efficient synthesis of highly substituted tetrahydroindazolone derivatives," Molecular Diversity, vol. 19, no. 3, pp. 473480, 2015.

[15] A. Piperno, A. Scala, F. Risitano, and G. Grassi, "Oxazol-5-(4H)ones. Part 1. Synthesis and reactivity as 1,3-dipoles," Current Organic Chemistry, vol. 18, no. 21, pp. 2691-2710, 2014.

[16] S. Roy, C. I. Bayly, Y. Gareau et al., "Maintenance of caspase-3 proenzyme dormancy by an intrinsic 'safety catch' regulatory tripeptide," Proceedings of the National Academy of Sciences of the United States of America, vol. 98, no. 11, pp. 6132-6137, 2001.

[17] D. Mandal, V. Baudin-Creuza, A. Bhattacharyya et al., "Caspase 3-mediated proteolysis of the $\mathrm{N}$-terminal cytoplasmic domain of the human erythroid anion exchanger 1 (Band 3)," The Journal of Biological Chemistry, vol. 278, no. 52, pp. 52551-52558, 2003.

[18] K. L. Wu, S. Khan, S. Lakhe-Reddy et al., "Renal tubular epithelial cell apoptosis is associated with caspase cleavage of the NHE1 $\mathrm{Na}^{+} / \mathrm{H}^{+}$exchanger," American Journal of PhysiologyRenal Physiology, vol. 284, no. 4, pp. F829-F839, 2003. 
[19] K. Pászty, A. K. Verma, R. Padányi, A. G. Filoteo, J. T. Penniston, and Á. Enyedi, "Plasma membrane $\mathrm{Ca}^{2+}$ ATPase isoform $4 \mathrm{~b}$ is cleaved and activated by caspase- 3 during the early phase of apoptosis," The Journal of Biological Chemistry, vol. 277, no. 9, pp. 6822-6829, 2002.

[20] F. Aredia and A. I. Scovassi, "Multiple effects of intracellular pH modulation in cancer cells," Cancer Cell \& Microenvironment, vol. 1, no. 2, p. 136, 2014.

[21] W. Nunomura, H. Wakui, Y. Takakuwa, and P. Gascard, "4.1 Proteins: ion transporters in check," Journal of Proteomics and Bioinformatics, vol. 6, no. 10, pp. 237-244, 2013.

[22] M. Karmazyn, M. Avkiran, and L. Fliegel, Eds., The SodiumHydrogen Exchanger. From Molecule to Its Role in Disease, vol. 318, Kluwer Academic Publishers, Dordrecht, The Netherlands, 2003.

[23] L. K. Putney, S. P. Denker, and D. L. Barber, "The changing face of the $\mathrm{Na}^{+} / \mathrm{H}^{+}$exchanger, NHE1: structure, regulation, and cellular actions," Annual Review of Pharmacology and Toxicology, vol. 42, pp. 527-552, 2002.

[24] D. Lagadic-Gossmann, L. Huc, and V. Lecureur, "Alterations of intracellular $\mathrm{pH}$ homeostasis in apoptosis: origins and roles," Cell Death and Differentiation, vol. 11, no. 9, pp. 953-961, 2004.

[25] H. Izumi, T. Torigoe, H. Ishiguchi et al., "Cellular pH regulators: potentially promising molecular targets for cancer chemotherapy," Cancer Treatment Reviews, vol. 29, no. 6, pp. 541-549, 2003.

[26] K. De Jong and F. A. Kuypers, "Flow cytometric determination of PMCA-mediated $\mathrm{Ca}^{2+}$-extrusion in individual red blood cells," Cytometry A, vol. 71, no. 9, pp. 693-699, 2007.

[27] K. Pászty, G. Antalffy, L. Hegedüs et al., "Cleavage of the plasma membrane $\mathrm{Ca}^{2+}$ ATPase during apoptosis," Annals of the New York Academy of Sciences, vol. 1099, pp. 440-450, 2007.

[28] M. J. Berridge, P. Lipp, and M. D. Bootman, "The versatility and universality of calcium signalling," Nature Reviews Molecular Cell Biology, vol. 1, no. 1, pp. 11-21, 2000.

[29] F. De Mattia, C. Gubser, M. M. T. Van Dommelen et al., "Human Golgi antiapoptotic protein modulates intracellular calcium fluxes," Molecular Biology of the Cell, vol. 20, no. 16, pp. 36383645, 2009.

[30] B. L. Schwab, D. Guerini, C. Didszun et al., "Cleavage of plasma membrane calcium pumps by caspases: a link between apoptosis and necrosis," Cell Death and Differentiation, vol. 9, no. 8, pp. 818-831, 2002.

[31] S. Pelengaris and M. Khan, Eds., The Molecular Biology of Cancer, Blackwell, Maldon, Mass, USA, 2006.

[32] Y. Feinstein-Rotkopf and E. Arama, "Can't live without them, can live with them: roles of caspases during vital cellular processes," Apoptosis, vol. 14, no. 8, pp. 980-995, 2009.

[33] D. Hanahan and R. A. Weinberg, "The hallmarks of cancer," Cell, vol. 100, no. 1, pp. 57-70, 2000.

[34] S. Ghavami, M. Hashemi, S. R. Ande et al., "Apoptosis and cancer: mutations within caspase genes," Journal of Medical Genetics, vol. 46, no. 8, pp. 497-510, 2009.

[35] E. C. LaCasse, D. J. Mahoney, H. H. Cheung, S. Plenchette, S. Baird, and R. G. Korneluk, "IAP-targeted therapies for cancer," Oncogene, vol. 27, no. 48, pp. 6252-6275, 2008.

[36] E. C. Ledgerwood and I. M. Morison, "Targeting the apoptosome for cancer therapy," Clinical Cancer Research, vol. 15, no. 2, pp. 420-424, 2009.

[37] E. Tellone, S. Ficarra, R. Scatena et al., "Influence of gemfibrozil on sulfate transport in human erythrocytes during the oxygenation-deoxygenation cycle," Physiological Research, vol. 57, no. 4, pp. 621-629, 2008.
[38] T. C. P. Dinis, V. M. C. Madeira, and L. M. Almeida, "Action of phenolic derivatives (acetaminophen, salicylate, and 5aminosalicylate) as inhibitors of membrane lipid peroxidation and as peroxyl radical scavengers," Archives of Biochemistry and Biophysics, vol. 315, no. 1, pp. 161-169, 1994.

[39] A. Russo, E. Tellone, S. Ficarra et al., "Band 3 protein function in teleost fish erythrocytes: effect of oxygenation-deoxygenation," Physiological Research, vol. 57, no. 1, pp. 49-54, 2008.

[40] S. Ficarra, F. Misiti, A. Russo et al., "Antiepileptic carbamazepine drug treatment induces alteration of membrane in red blood cells: possible positive effects on metabolism and oxidative stress," Biochimie, vol. 95, no. 4, pp. 833-841, 2013.

[41] A. Galtieri, E. Tellone, S. Ficarra et al., "Resveratrol treatment induces redox stress in red blood cells: a possible role of caspase 3 in metabolism and anion transport," Biological Chemistry, vol. 391, no. 9, pp. 1057-1065, 2010.

[42] G. L. Ellman, “Tissue sulfhydryl groups," Archives of Biochemistry and Biophysics, vol. 82, no. 1, pp. 70-77, 1959.

[43] G. L. Ellman, K. D. Courtney, V. Andres Jr., and R. M. Featherstone, "A new and rapid colorimetric determination of acetylcholinesterase activity," Biochemical Pharmacology, vol. 7, no. 2, pp. 88-95, 1961.

[44] H. A. M. Andree, C. P. M. Reutelingsperger, R. H. Mann, H. C. Hemker, W. T. Hermens, and G. M. Willems, "Binding of vascular anticoagulant $\alpha$ (VAC $\alpha)$ to planar phospholipid bilayers," Journal of Biological Chemistry, vol. 265, no. 9, pp. 4923-4928, 1990.

[45] E. Tellone, M. C. De Rosa, D. Pirolli et al., "Molecular interactions of hemoglobin with resveratrol: potential protective antioxidant role and metabolic adaptations of the erythrocyte," Biological Chemistry, vol. 395, no. 3, pp. 347-354, 2014.

[46] E. Tellone, S. Ficarra, B. Giardina et al., "Oxidative effects of gemfibrozil on anion influx and metabolism in normal and beta-thalassemic erythrocytes: physiological implications," Journal of Membrane Biology, vol. 224, no. 1-3, pp. 1-8, 2008.

[47] E. Tellone, S. Ficarra, A. Russo et al., "Caffeine inhibits erythrocyte membrane derangement by antioxidant activity and by blocking caspase 3 activation," Biochimie, vol. 94, no. 2, pp. 393402, 2012.

[48] G.-H. Fu, Y. Wang, Y.-H. Xi et al., "Direct interaction and cooperative role of tumor suppressor p16 with band 3 (AE1)," FEBS Letters, vol. 579, no. 10, pp. 2105-2110, 2005.

[49] W.-W. Shen, J. Wu, L. Cai et al., "Expression of anion exchanger 1 sequestrates p16 in the cytoplasm in gastric and colonic adenocarcinoma," Neoplasia, vol. 9, no. 10, pp. 812-819, 2007.

[50] A. Bogdanova, A. Makhro, J. Wang, P. Lipp, and L. Kaestner, "Calcium in red blood cells-a perilous balance," International Journal of Molecular Sciences, vol. 14, no. 5, pp. 9848-9872, 2013.

[51] C. Mallozzi, A. M. M. Di Stasi, and M. Minetti, "Nitrotyrosine mimics phosphotyrosine binding to the $\mathrm{SH} 2$ domain of the $s r c$ family tyrosine kinase lyn," FEBS Letters, vol. 503, no. 2-3, pp. 189-195, 2001.

[52] T. McFate, A. Mohyeldin, H. Lu et al., "Pyruvate dehydrogenase complex activity controls metabolic and malignant phenotype in cancer cells," Journal of Biological Chemistry, vol. 283, no. 33, pp. 22700-22708, 2008.

[53] R. L. Franco, N. G. Schenka, A. A. Schenka, L. F. Rezende, and M. S. Gurgel, "Glutathione S-transferase Pi expression in invasive breast cancer and its relation with the clinical outcome," Journal of BUON, vol. 17, pp. 259-264, 2012. 
[54] S. Ficarra, E. Tellone, B. Giardina et al., "Derangement of erythrocytic AE1 in $\beta$-thalassemia by caspase 3: pathogenic mechanisms and implications in red blood cell senescence," Journal of Membrane Biology, vol. 228, no. 1, pp. 43-49, 2009.

[55] D. Mandal, P. K. Moitra, S. Saha, and J. Basu, "Caspase 3 regulates phosphatidylserine externalization and phagocytosis of oxidatively stressed erythrocytes," FEBS Letters, vol. 513, no. 2-3, pp. 184-188, 2002.

[56] D. Mandal, A. Mazumder, P. Das, M. Kundu, and J. Basu, "Fas-, caspase 8-, and caspase 3-dependent signaling regulates the activity of the aminophospholipid translocase and phosphatidylserine externalization in human erythrocytes," The Journal of Biological Chemistry, vol. 280, no. 47, pp. 3946039467, 2005.

[57] D. W. Nicholson and N. A. Thornberry, "Caspases: killer proteases," Trends in Biochemical Sciences, vol. 22, no. 8, pp. 299-306, 1997.

[58] J. R. Schelling and B. G. Abu Jawdeh, "Regulation of cell survival by $\mathrm{Na}+\mathrm{H}+$ exchanger-1," American Journal of PhysiologyRenal Physiology, vol. 295, no. 3, pp. F625-F632, 2008.

[59] H. Barrière, C. Poujeol, M. Tauc, J. M. Blasi, L. Counillon, and P. Poujeol, "CFTR modulates programmed cell death by decreasing intracellular $\mathrm{pH}$ in Chinese hamster lung fibroblasts," American Journal of Physiology - Cell Physiology, vol. 281, no. 3, pp. C810-C824, 2001.

[60] P. Swietach, T. Tiffert, J. M. A. Mauritz et al., "Hydrogen ion dynamics in human red blood cells," Journal of Physiology, vol. 588, no. 24, pp. 4995-5014, 2010.

[61] B. A. Webb, M. Chimenti, M. P. Jacobson, and D. L. Barber, "Dysregulated pH: a perfect storm for cancer progression," Nature Reviews Cancer, vol. 11, no. 9, pp. 671-677, 2011.

[62] A. Gorbatenko, C. W. Olesen, E. Boedtkjer, and S. F. Pedersen, "Regulation and roles of bicarbonate transporters in cancer," Frontiers in Physiology, vol. 5, article 130, Article ID Article 130, 2014.

[63] J. M. Rifkind and E. Nagababu, "Hemoglobin redox reactions and red blood cell aging," Antioxidants and Redox Signaling, vol. 18, no. 17, pp. 2274-2283, 2013.

[64] M. Föller, S. M. Huber, and F. Lang, "Erythrocyte programmed cell death," IUBMB Life, vol. 60, no. 10, pp. 661-668, 2008.

[65] J. L. Lelli Jr., L. L. Becks, M. I. Dabrowska, and D. B. Hinshaw, "ATP converts necrosis to apoptosis in oxidant-injured endothelial cells," Free Radical Biology and Medicine, vol. 25, no. 6, pp. 694-702, 1998.

[66] D. Anastasiou, G. Poulogiannis, J. M. Asara et al., "Inhibition of pyruvate kinase M2 by reactive oxygen species contributes to cellular antioxidant responses," Science, vol. 334, no. 6060, pp. 1278-1283, 2011. 


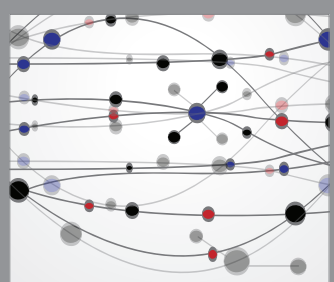

The Scientific World Journal
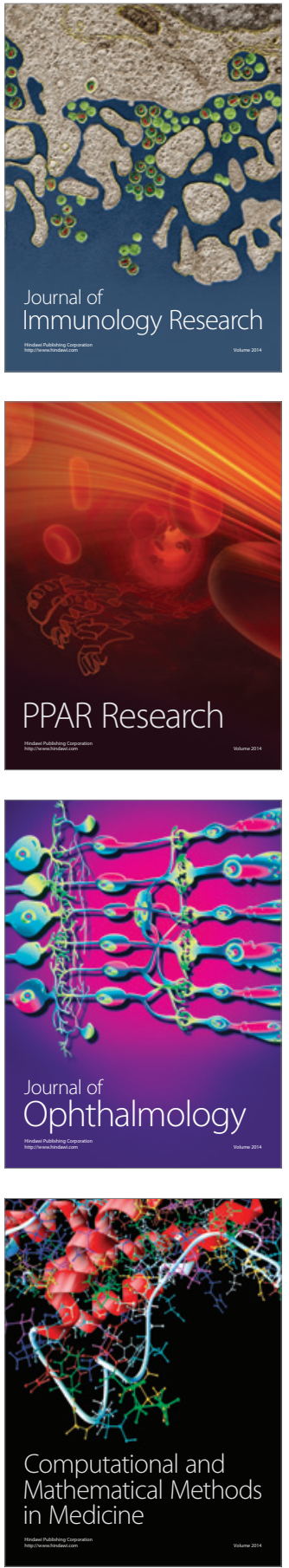

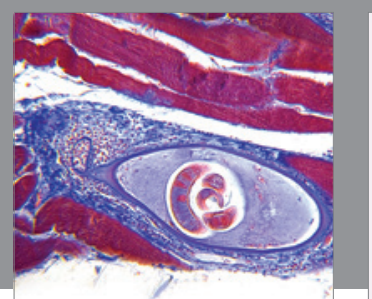

Gastroenterology Research and Practice

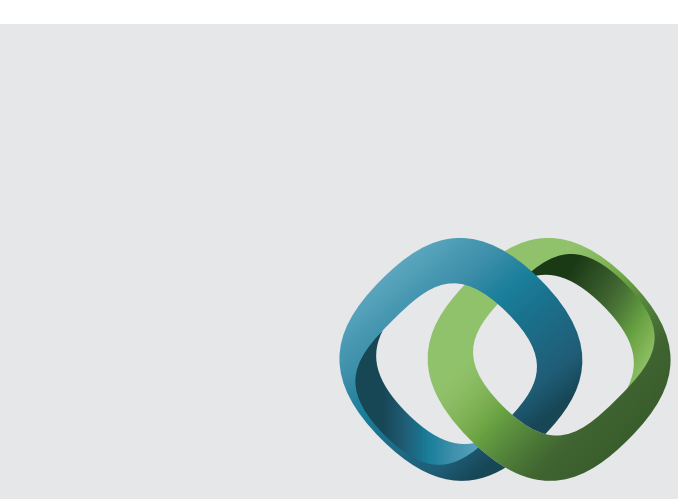

\section{Hindawi}

Submit your manuscripts at

http://www.hindawi.com
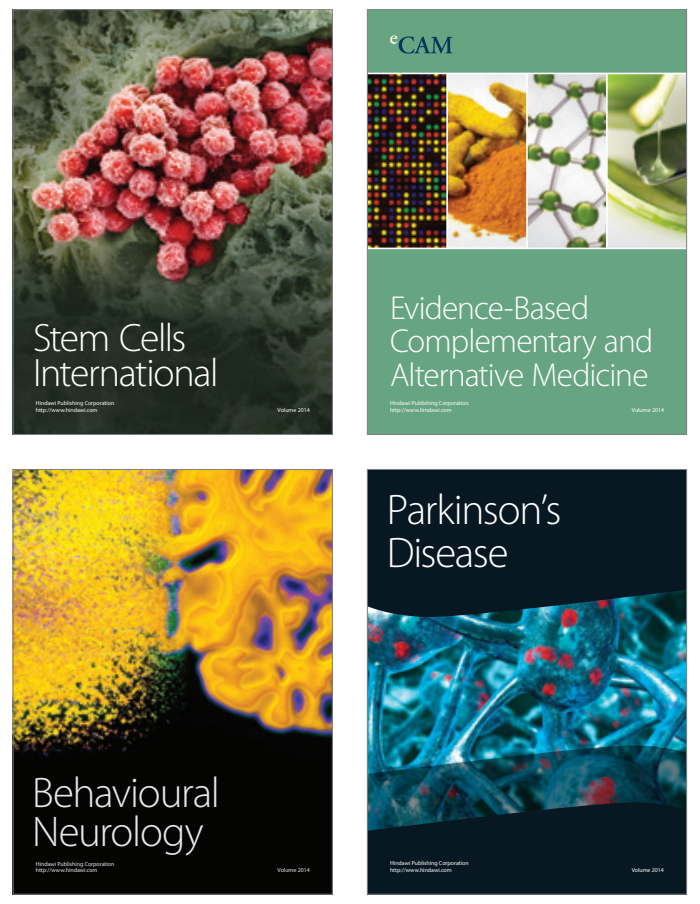
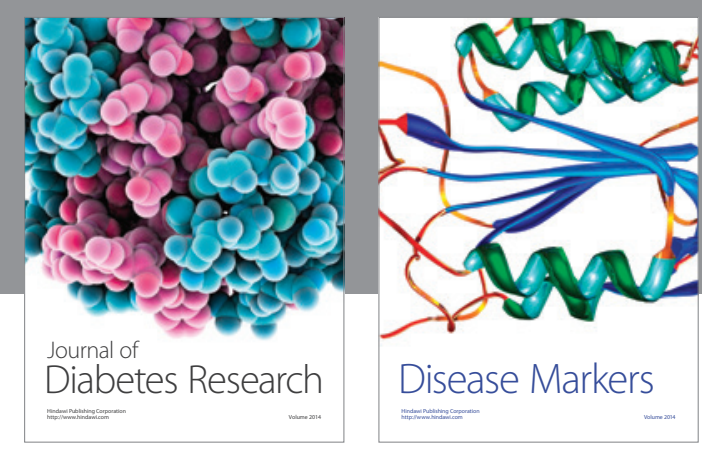

Disease Markers
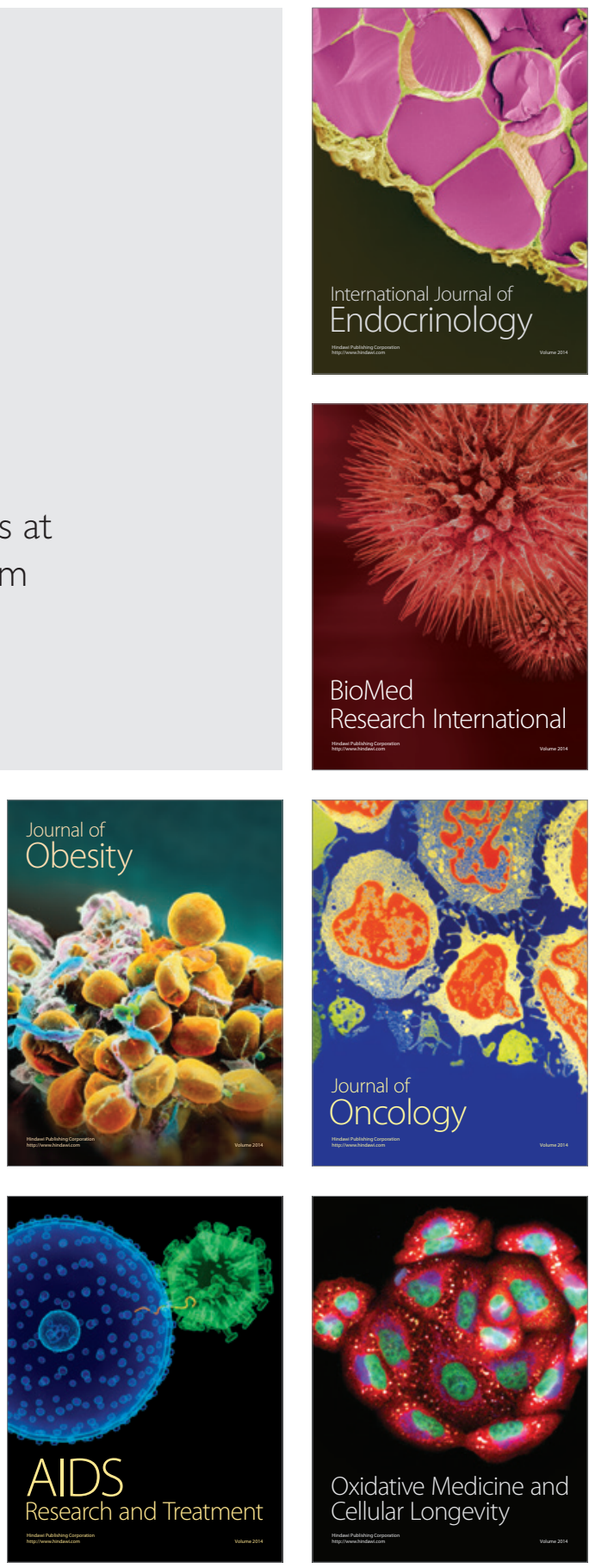